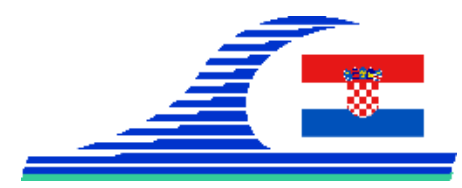

\title{
Adriatic karstic estuaries, their characteristics and evolution
}

\section{Mladen JURAČIĆ ${ }^{1}$}

1. University of Zagreb, Faculty of Science, Department of Geology, Horvatovac 102a, 10000 Zagreb, Croatia.

mjuracic@geol.pmf.hr

\begin{abstract}
:
The coastal area of the eastern Adriatic is characterized with a prevalence of carbonate rocks and well-developed karst. Present freshwater input into the Adriatic is quite large, mostly through coastal and submarine springs. However, there are also a number of rivers debouching in the Adriatic from the eastern coast. Most of them have canyon like fluviokarstic valleys that were carved dominantly during Pleistocene and were drowned during post-LGM sea-level rise forming estuaries. These estuaries are filled to a different extent during Holocene highstand (last 7.500 years). The intraestuarine delta progradation is rather different in those estuaries depending on the quantity of the riverborne material. Human impact on progradation rate in some of the estuaries has been shown.
\end{abstract}

\section{Keywords:}

Estuaries, Sedimentation, Intraestuarine delta, Progradation, Allogenic river, Anthopogenic influence. 
Mediterranean rocky coasts:

Features, processes, evolution and problems

\section{Introduction}

Eastern Adriatic coastal area is formed predominantly in Mesozoic carbonate rocks with well-developed karst (PIKELJ \& JURAČIĆ, 2013). Due to prevalent humid climatic conditions and karst maturation present freshwater input into the Adriatic is large, mostly through coastal and submarine springs (vruljas). However, there are also a number of rivers debouching into the Adriatic. These rivers have some common characteristics, but also differences. Obviously, they have fluvio-karstic valleys which have been drowned by the sea-level rise during post-Late Glacial Maximum (LGM) transgression. So formed (karstic) estuaries are gradually filled with river-borne material. The aim of this paper is to present and discuss common and specific characteristics and differences of Adriatic karstic estuaries and to indicate a human influence on their evolution.

\section{Evolution of karstic estuaries}

Rivers debouching into the Adriatic sea along the eastern coast have lower reaches of their valleys carved in carbonates (predominately Cretaceous and Eocene limestone), whereas upper part of their catchment area is formed either in flysch (e.g. rivers Dragonja, Mirna, Raša, Rječina, Jadro) or in other impermeable rocks (clastics, magmatic \& metamorphic rocks) (e.g. rivers Nerteva, Krka, Zrmanja) (JURAČIĆ, 1998). Therefore the term allogenic karstic rivers can be applied to them.

Most of the rivers in lower reaches have well-developed canyon-like valleys (JURAČIĆ \& PROHIĆ, 1991; JURAČIĆ, 1992). These fluviokarstic valleys were presumably carved dominantly in Pleistocene (BENAC et al., 2013), while the sea-level was up to $120 \mathrm{~m}$ lower than the present one.

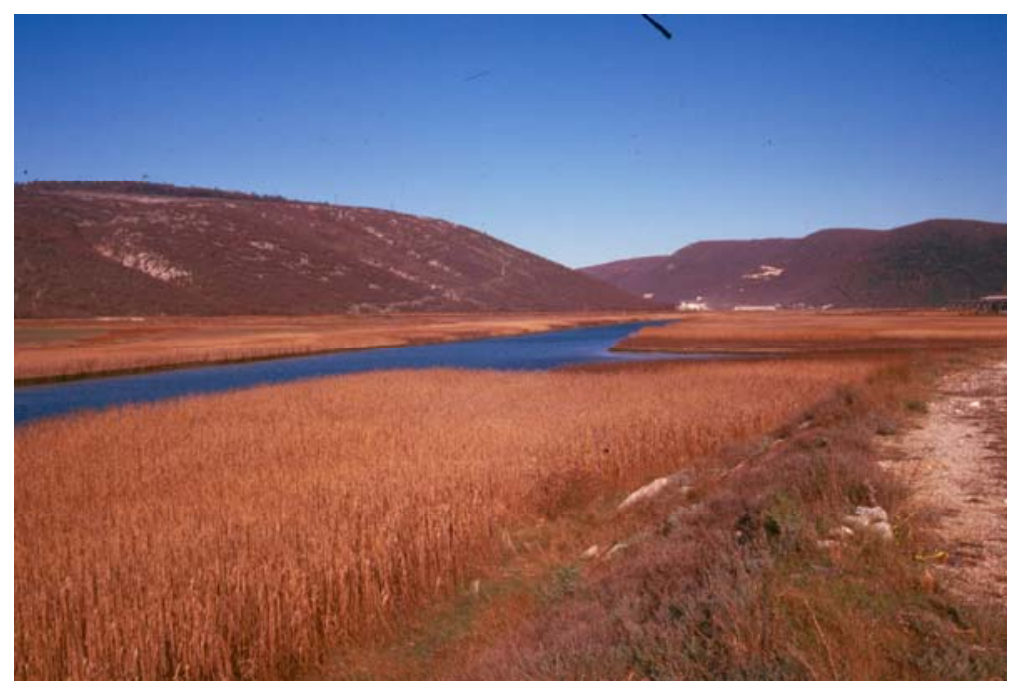


Figure 1. Raša River valley caved in Cretaceous limestone with prograding intraestuarine delta.

During post-LGM sea-level rise (between 19.000 to 7.500 y BP) the sea drowned these valleys and karstic estuaries were formed. Example of the Raša River valley carved into Cretaceous limestone is shown in Figure 1.

\section{Intraestuarine delta progradation}

After the sea-level rise ceased (7.500 yBP), gradual filling of estuaries with river-borne material started. This material is predominantly alumosilicate reflecting lithology of the catchment area. The degree of intraestuarine ("bayhead") delta progradation (SEMENIUK \& SEMENIUK, 2016) is rather different, depending on the quantity of the river-borne material. Extreme examples of Krka River estuary without intraestuaerine delta and Neretva River delta are shown in Figure 2.
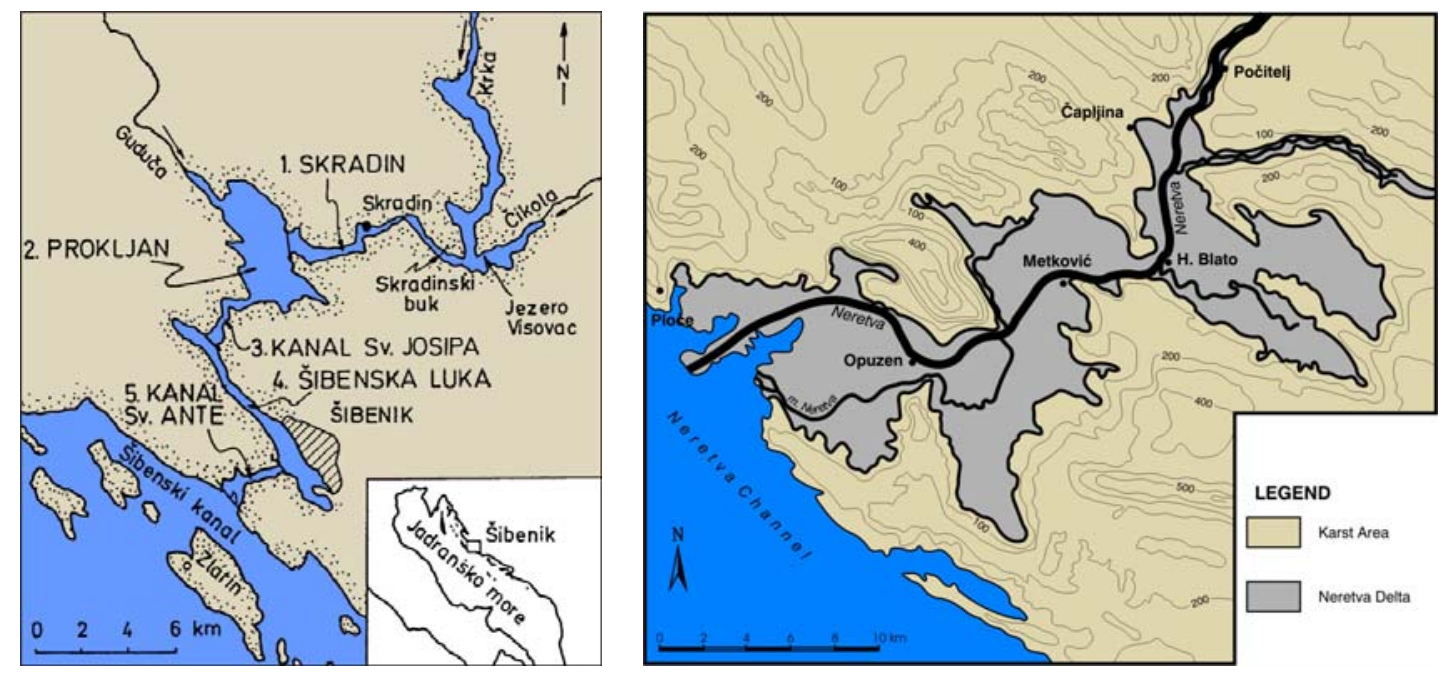

Figure 2. Comparison of the Krka River mouth (deep karstic estuary; left) and Neretva River mouth (intraestuarine deltaic sediments filled former river valley-estuary; right).

The main factor governing the formation and progradation of the intraestuarine delta is size and weathering rate of the noncarbonated part of the catchment area on one hand, and formation and existence of in the river watercourse on the other. For example Krka and Zrmanja rivers have a rather small part of the catchment developed in noncarbonate rocks, and have well-developed calc tufa barriers along the watercourse, and therefore have no intrestuarine delta (JURAČIĆ \& PROHIĆ, 1991; JURAČIĆ, 1992), whereas Mirna and Neretva rivers have their estuaries already almost filled with alluvial sediments (FELJA et al., 2015; JURAČIĆ, 1998; FELJA, 2017). Progradation of their 
Mediterranean rocky coasts:

Features, processes, evolution and problems

intraestuarine delta has been shown to be very rapid since $7.500 \mathrm{yBP}(11 \mathrm{~km}$ in the Mirna River estuary, and up to $25 \mathrm{~km}$ in the Neretva River mouth, FELJA, 2017). An example of the partially filled estuary is the Raša River mouth, where delta progradation of $2 \mathrm{~km}$ in 200 years has been documented (BENAC et al., 1991; SONDI et al., 1995) (Figure 3). Due to the fact that in the catchment of both Mirna and Raša rivers dominate flysh with a large share of marl, both intraestuarine deltas are characterized with finegrained muddy sediments (SONDI et al., 1995; FELJA et al., 2015).
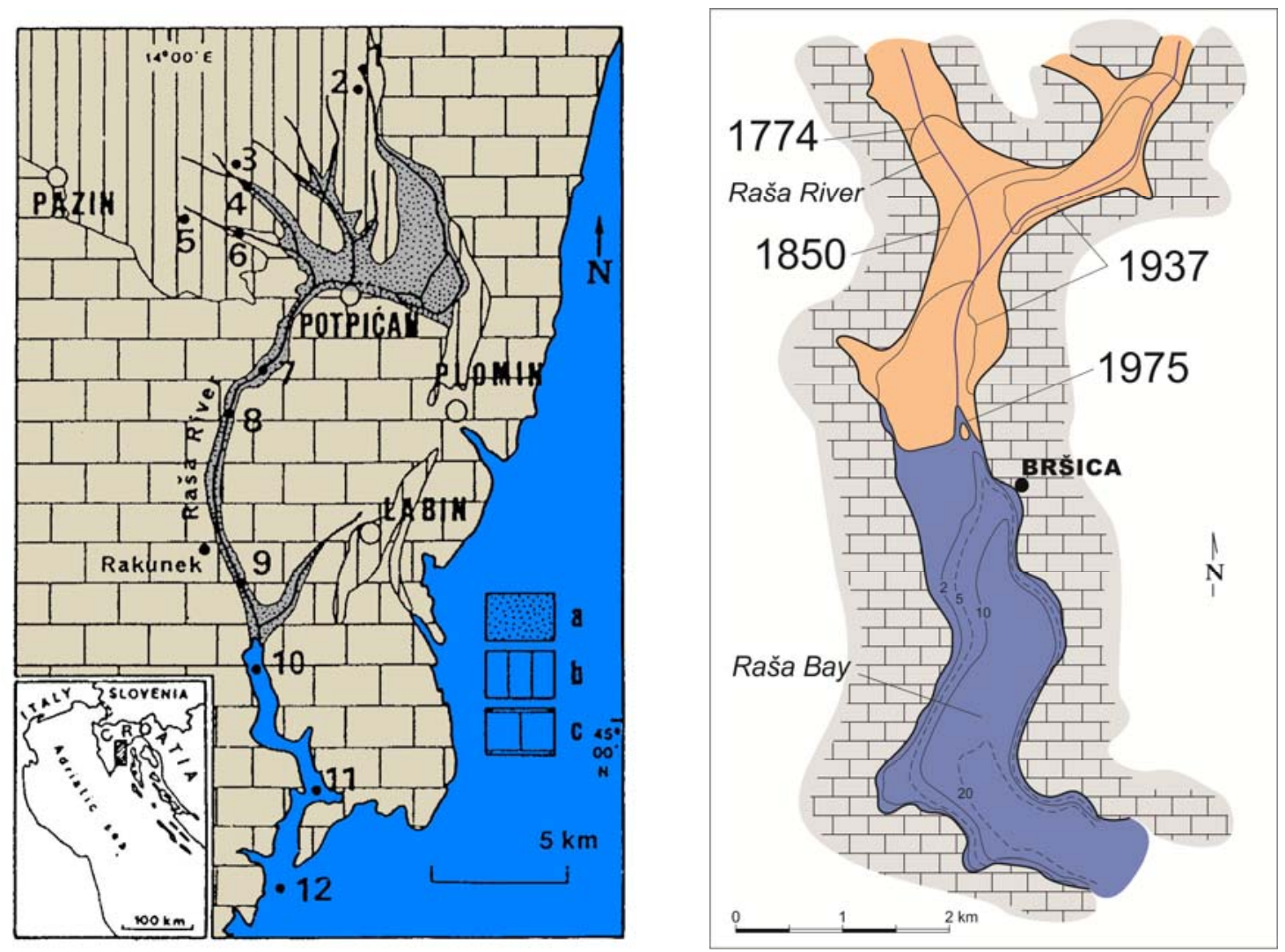

Figure 3. The Raša River catchment lithology ( $a=$ alluvial sediments; $b=$ flysch; $c=$ limestone) on the left and Raša intraestuarine delta progradation (after BENAC, 1991) on the right).

\section{Anthropogenic impact}

Investigation of the sedimentation in karstic river mouths along the Adriatic coast revealed that human impact on some of them is rather large. In the case of the Mirna River estuary, its intraestuarine delta progradation was accelerated from $15^{\text {th }}$ to $19^{\text {th }}$ century due to deforestation and agriculturization of the catchment area, which caused much faster erosion of flysch terrains (FELJA, 2017). The opposite, deceleration of Neretva river delta progradation and accumulation of much finer sediments occurred 
Mediterranean rocky coasts:

Features, processes, evolution and problems

during the $20^{\text {th }}$ century due to damming of upper reaches of the river in order to build hydropower plants (JURAČĆĆ, 1998).

\section{Conclusions}

Karstic character of the eastern Adriatic coast caused the formation of peculiar river mouths which can be termed karstic estuaries. Their common characteristics are that fluviokarstic river valleys carved in carbonates were flooded during post-LGM sea-level rise forming long elongated estuaries. The degree of their filling with prevalently alumosilicate material depends mostly on the percent of allogenic riverine input. Therefore these estuaries can remain long narrow estuaries (e.g. Krka and Zrmanja rivers) be partially filled (e.g. Raša River) or can be almost filled forming large delta plains (e.g. Mirna and Neretva rivers). Anthropogenic influence on its development can be substantial.

\section{References}

BENAC Č., ARBANAS Ž., PAVLOVEC E. (1991). Origin and geotechnical characteristics of the Raša valley and bay (in Croatian), Pomorski zbornik, Vol. 29, pp. 475-429.

BENAC Č., JURAČIĆ M., MATIČEC D., RUŽIĆ I., PIKELJ K. (2013). Fluviokarst and classical karst: Examples from the Dinarics (Krk Island, Northern Adriatic, Croatia). Geomorphology, Vol. 184, pp. 64-73. doi.org/10.1016/j.geomorph.2012.11.016

FELJA I., FONTANA A., FURLANI S., BAJRAKTAREVIĆ Z., PARADŽIK A., TOPALOVIĆ E., ROSSATO S., ĆOSOVIĆ V., JURAČIĆ M. (2015). Environmental changes in the lower Mirna River valley (Istria, Croatia) during the Middle and Late Holocene. Geologia Croatica, Vol. 68 (3), pp. 209-224. http://dx.doi.org/10.4154/gc.2015.16

FELJA I. (2017). Karstic estuaries along the eastern Adriatic coast: Late-Quaternary evolution of the Mirna and Neretve River mouths. PhD Thesis, University of Zagreb, Croatia, $169 \mathrm{p}$.

JURAČIĆ M., PROHIĆ E. (1991). Mineralogy, sources of particles, and sedimentation in the Krka River estuary. Geološki Vjesnik, Vol. 44, pp.195-200.

JURAČIĆ M. (1992). Sedimentation in some Adriatic karstic river mouths. (Are they estuaries or rias?). Proceedings of the conference Geomorphology and the sea, Mali Lošinj, 1992. Department of Geography, Faculty of Science, University of Zagreb, pp. 55-63.

JURAČIĆ M. (1998). O nastanku i promjenama delte rijeke Neretve. Dubrovnik, Časopis za književnost i znanost, Nova serija, god. Vol. IX (4), Matica hrvatska Dubrovnik, pp. 228-232.

PIKELJ K., JURAČIĆ M. (2013). Eastern Adriatic Coast (EAC): Geomorphology and Coastal Vulnerability of a Karstic Coast. Journal of Coastal Research, Vol. 29 (4), pp. 944-957. doi.org/10.2112/JCOASTRES-D-12-00136.1 
Mediterranean rocky coasts:

Features, processes, evolution and problems

SEMENIUK V., SEMENIUK C. (2016). Deltas. In Kennish M. J. ed., Encyclopedia of Estuaries, Springer References, Dodrecht, pp. 177- 187. DOI 10.1007/978-94-017-8801-4 SONDI I., JURACIC M., PRAVDIC V. (1995). Sedimentation in a disequilibrium river-dominated estuary. The Raša River Estuary (Adriatic Sea-Croatia). Sedimentology, Vol. 42, pp. 769-782. doi.org/10.1111/j.1365-3091.1995.tb00408.x 